\title{
The effect of light intensity and shear stress on microbial biostabilization and the community composition of natural biofilms
}

This article was published in the following Dove Press journal:

Research and Reports in Biology

\author{
Holger Schmidt ${ }^{\prime}$ \\ Moritz Thom ${ }^{2}$ \\ Silke Wieprecht ${ }^{3}$ \\ Werner Manz' \\ Sabine Ulrike Gerbersdorf ${ }^{3}$ \\ 'Institute for Integrated Natural \\ Sciences, University of Koblenz- \\ Landau, Koblenz, ${ }^{2}$ Forschungszentrum \\ Küste, Leibniz Universität Hannover, \\ Hannover, ${ }^{3}$ Institute for Modelling \\ Hydraulic and Environmental Systems, \\ University of Stuttgart, Stuttgart, \\ Germany
}

\begin{abstract}
Biofilms constitute an important issue in microbial ecology, due to their high ecological and economic relevance, but the impact of abiotic conditions and microbial key players on the development and functionality of a natural biofilm is still little understood. This study investigated the effects of light intensity (LI) and bed shear stress (BSS) and the role of dominant microbes during the formation of natural biofilms and particularly the process microbial biostabilization. A comprehensive analysis of microbial biomass, extracellular polymeric substances produced, and the identification of dominant bacterial and algal species was correlated with assessment of biofilm adhesiveness/stability. LI and BSS impacted the biofilms in very different ways: biofilm adhesiveness significantly increased with LI and decreased with BSS. Moreover, microbial biomass and the functional organization of the bacterial community increased with LI, while the dynamics in the bacterial community increased with BSS. Most stable biofilms were dominated by sessile diatoms like Achnanthidium minutissimum or Fragilaria pararumpens and bacteria with either filamentous morphology, such as Pseudanabaena biceps, or a potential high capacity for extracellular polymeric-substance production, such as Rubrivivax gelatinosus. In contrast, microbes with high motility, such as Nitzschia fonticola, Pseudomonas fluorescens, and Caulobacter vibrioides, dominated the least adhesive biofilms. Their movement and potential antibiotic production could have had a disruptive impact on the biofilm matrix, which decreased its stability. This is the first study to unveil the link between abiotic conditions and resulting shifts in key microbial players to impact the ecosystem-service microbial biostabilization.
\end{abstract}

Keywords: microbial biostabilization, natural biofilms, abiotic factors, microbial community, mesocosm

\section{Introduction}

For approximately 20 years, biofilms have been recognized as increasingly important subjects of research. This is due to their high economic importance, whether they are regarded as beneficial, eg, in the context of bioremediation, ${ }^{1,2}$ or as adverse, eg, by biofouling ${ }^{3-5}$ or colmation of riverine sediments. ${ }^{6}$ Most studies have focused on one of two fundamental perspectives: the impact of environmental conditions on the development and characteristics of biofilms, or "performance", eg, the rate of nutrient cycling or contaminant retention of the biofilm system. Thereby, the influence of different environmental factors has been investigated in view of the biofilm structure, ${ }^{7}$ the metabolism pathways, ${ }^{8-10}$ or the development of the microbial community. ${ }^{11,12}$ Further studies have investigated the role of biotic factors, such as predation on the formation and functionality of microbial biofilms. ${ }^{13,14}$ As a result, knowledge about the
Correspondence: Sabine Ulrike Gerbersdorf

Institute for Modelling Hydraulic and Environmental Systems, University of Stuttgart, Pfaffenwaldring 6I, 70569

Stuttgart, Germany Email sabine.gerbersdorf@iws.unistuttgart.de
Research and Reports in Biology 2018:9 I-16

(c) (i) (5) 2018 Schmidt et al. This work is published and licensed by Dove Medical Press Limited. The full terms of this license are available at https://www.dovepress.com/terms. Dovepress if in $>$ 
impact of important environmental conditions, such as light or nutrient availability, upon biofilm systems is constantly increasing to unravel different feedback loops between biofilm and environment.

However, the process of microbial biostabilization of fine sediments ${ }^{15}$ is still poorly understood, despite growing literature focusing on this essential ecosystem function. Many recent studies have concentrated on the role of different components in the extracellular polymeric substance (EPS) matrix, ${ }^{16,17}$ as these substances are generally considered driving factors for biostabilization. In this regard, the important role of algal EPS production has been highlighted, ${ }^{18}$ as well as the essential role of bacterial EPS. ${ }^{19}$ However, if EPS constitutes the determining factor for the stability of biofilms and fine sediments, it is affected by various boundary conditions. As an example, it has been shown that different diatoms produce EPS with differing characteristics, ${ }^{20-22}$ suggesting a significant influence of microbial key players. Moreover, abiotic environmental factors impact the development of the microbial community, increasing the degree of complexity of research on the stabilizing potential of biofilms. As these boundary conditions are constantly changing during field experiments, fundamental research on this subject appears feasible only via the usage of mesocosm experiments (with sufficient replicates), where abiotic environmental parameters can be controlled and biofilms cultivated under constant, reproducible natural-like boundary conditions. Using an experimental setup whose design and reliability have been previously demonstrated, ${ }^{23}$ the impact of abiotic environmental conditions on microbial biostabilization can be assessed, ${ }^{24}$ albeit without including detailed information on the composition of the microbial community and the specific role of potential microbial key players in the process of biostabilization. Therefore, the focus of this study was to gather comprehensive insight into the impact of two major abiotic environmental factors (flow velocity and light intensity [LI]) on the development of biofilms and their functionality, with special consideration of microbial community composition.

\section{Materials and methods Experimental setup}

Cultivation of biofilms was performed under constant naturallike environmental conditions in a mesocosm consisting of six straight flumes, each with an individual, separate water circuit. ${ }^{24}$ Briefly, individual flumes (see Figure 1; length $\times$ width $\times$ height: $3 \times 0.15 \times 0.15 \mathrm{~m}$ ) were designed to allow a homogeneous flow field and constant bed shear stress (BSS) across the biofilm-cultivation section (length $1.32 \mathrm{~m}$ ). This section contained 16 substratum cartridges (length $\times$ width $\times$ height $0.08 \times 0.06 \times 0.02 \mathrm{~m}$ ) that could be transferred outside the flume for further measurements. These cartridges were illuminated by two parallel fluorescent tubes (Osram Biolux; 480-665 nm). The distance of these light sources to the sediment surface was adjustable, resulting in different LI during an 8/16-hour day/night cycle for the sediment and biofilm surface. Homogenous irradiation was confirmed by measurements of LI and wavelength irradiance of the photosynthetic active radiation (PAR) spectrum using high-resolution spectroradiometry (SR-9910; Macam Photometrics, Livingston, Scotland). ${ }^{25}$ The resulting flow velocity and BSS affecting the surface of both the sediment and biofilms could be regulated by adjusting the bypass. Discharge was continuously measured with an installed miniflowmeter (8030; Bürkert, Ingelfingen, Germany). Comparability of biofilm growth in this mesocosm has been shown previously. ${ }^{23}$ On the first day of each experiment, the inoculum for biofilm cultivation, consisting of fluvial water and swirled-up fine river sediment was retrieved from the River Enz (Baden-Württemberg, Germany, $48^{\circ} 56^{\prime} 0.63^{\prime \prime} \mathrm{N} 8^{\circ} 55^{\prime} 3.54$ 'E). Kept at constant temperature $\left(15^{\circ} \mathrm{C} \pm 0.3^{\circ} \mathrm{C}\right)$ by a cooling water circuit, $200 \mathrm{~L}$ was circulated in each flume by a circulatory pump (Badu Eco Touch; Speck Pumpen, Neunkirchen am Sand, Germany) for the duration of the experiments (overview given in Table 1). Indigenous microorganisms within the river water settled the cartridges filled with inert glass beads (diameter 100-200 $\mu \mathrm{m}$ ), forming a biofilm.

\section{Experiments and sampling}

Seasonality has a strong influence on biofilm growth, with a clear maximum in biostabilization during spring. ${ }^{26}$ As such, biofilm development was assessed in two experiments during spring 2013 and 2014 (Table 1), and abiotic boundary conditions were set in three natural-like levels (see Table 2). In this context, applied levels of BSS ranged from a situation with very low flow velocity, such as in shallow reaches of abandoned meanders, up to physical stress closed to the point of erosion of the used fine sediment. The LI reflected the situation of virtually no illumination penetrating the water column and reaching the river bed, eg, in very turbid and/or heavily shaded rivers up to very high levels of irradiation, as found in very shallow reaches illuminated by bright sunlight during the midday hours.

To address the well-known patchiness and heterogeneity of biofilms on the microscale, ${ }^{27}$ at each sampling point, half of the sediment surface of one cartridge was sampled, withdrawing 15 biofilm samples with a cutoff $2 \mathrm{~mL}$ syringe 


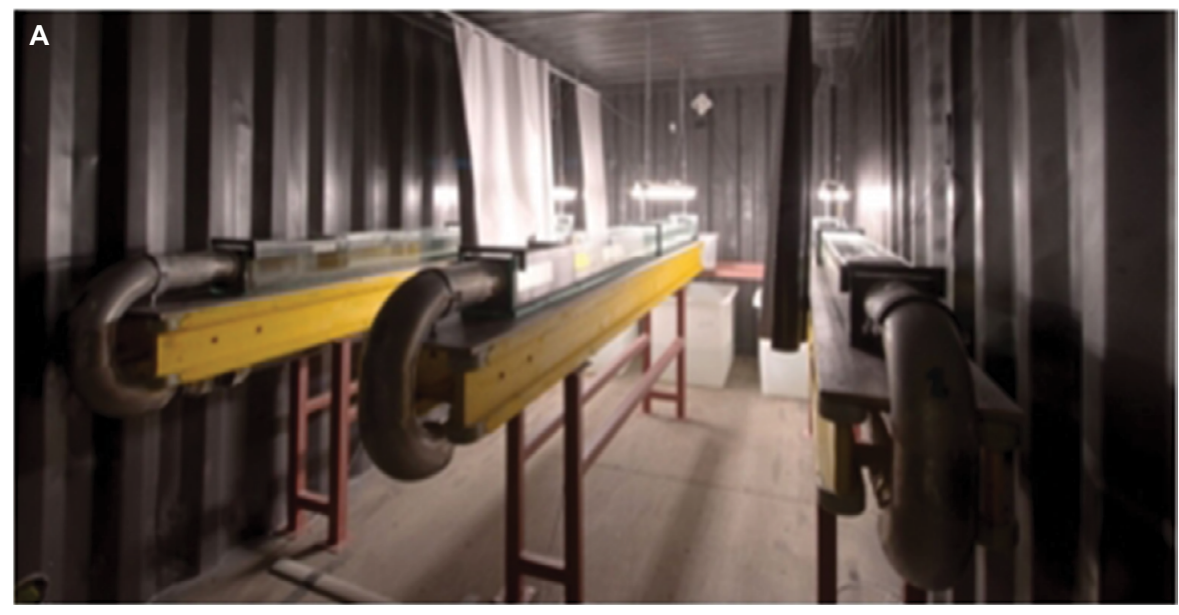

B

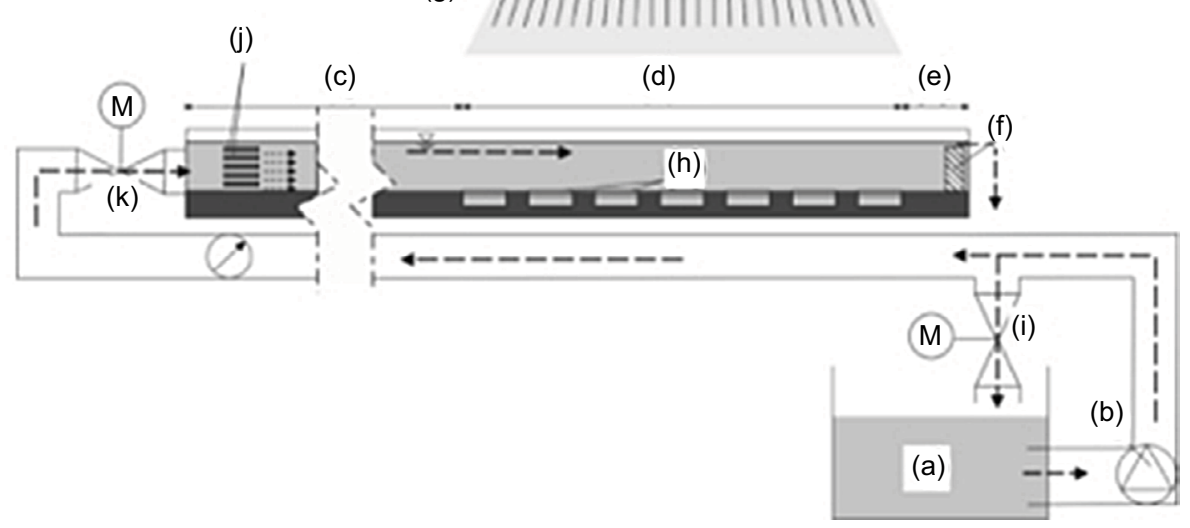

Figure I Experimental setup.

Notes: (A) Image of three equivalent straight flumes installed in one containers. (B) Schematic image of one straight flume. Outflow tank (a), pump (b), inlet-flow section with baffles (c), biofilm-cultivation section (d), outlet-flow section (e), weir (f), fluorescent tubes $(\mathrm{g})$, sediment cartridges (h), bypass (i), current abatement (j), fine-tuning valve (k), valve (M). Figure B reprinted from Int J Sediment Res. 2015;30(4). Thom M, Schmidt H, Gerbersdorf SU, Wieprecht S. Seasonal biostabilization and erosion behavior of fluvial biofilms under different hydrodynamic and light conditions. Pages 273-284. Copyright $\odot 2015$ International Research and Training Centre on Erosion and Sedimentation/the World Association for Sedimentation and Erosion Research. Published by Elsevier B.V. All rights reserved. With permission from Elsevier. ${ }^{24}$

Table I Overview of experiments

\begin{tabular}{llllll}
\hline Experiment & Duration & Flume & BSS & LI & Sampling days \\
\hline May & April 30-June 7, & 1 & Maximum & Medium & \\
& 2013 & 2 & Medium & Medium & \\
& & 3 & Minimum & Medium & $4,7,11,14,18,21,25,28,32,35$ \\
& & 4 & Minimum & Medium & Medium \\
March & 5 & Medium & Medium & \\
& March 18-April & 6 & Maximum & Medium & \\
& 29,2014 & 2 & Minimum & Maximum & \\
& & 3 & Minimum & Minimum & $4,7,11,14,18,21,25,28,32,35,39$ \\
& & 4 & Minimum & Medium & \\
\hline
\end{tabular}

Abbreviations: BSS, bed shear stress; LI, light intensity.

(diameter $0.01 \mathrm{~m}$ ). The gathered material was pooled to obtain representative results, subsamples $\left(0.5\right.$ or $\left.1 \mathrm{~cm}^{3}\right)$ transferred into Eppendorf tubes for further analyses, and $1 \mathrm{~L}$ of water collected for chemical analyses. Furthermore, analysis of all results reflected the two different successional development stages of the biofilm (nascent bacteria dominated until day 18 , and matured algae dominated from day 21 onward). 
Table 2 Abiotic boundary conditions in experiments

\begin{tabular}{|c|c|c|}
\hline & 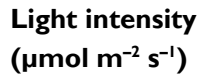 & $\begin{array}{l}\text { Bed shear stress } \\
\left(\mathrm{N} \mathrm{m}^{-2}\right)\end{array}$ \\
\hline Minimum & 0 & 0.02 \\
\hline Medium & 50 & 0.04 \\
\hline Maximum & 100 & 0.08 \\
\hline
\end{tabular}

\section{Analyses}

\section{Water chemistry, EPS, and microbial biomass}

The concentration of ammonia ions in the water samples was analyzed according to DIN 38406-E5-1. Concentrations of chloride ions were determined according to DIN EN ISO 10304. In addition, nitrate, phosphate, fluoride, and sulfate ions were determined using a quick test (detection limits, nitrate $1 \mathrm{mg} / \mathrm{L}$, phosphate $0.1 \mathrm{mg} / \mathrm{L}$, fluoride $0.1 \mathrm{mg} / \mathrm{L}$, sulfate $5.8 \mathrm{mg} / \mathrm{L}$; Hach Lange $\mathrm{GmbH}$, Düsseldorf, Germany). Colloidal EPS fractions of the biofilms were extracted as per Gerbersdorf et al. ${ }^{28}$ Carbohydrates and protein contents were measured by phenol assay and modified Lowry procedure in triplicate. ${ }^{29-31}$ According to the DIN 38 412/16 protocol, chlorophyll $a$ contents were measured in ethanol extracts before and after acidification. For determination of bacterial cell count (BCC), samples were fixed with $4 \%$ paraformaldehyde (final concentration), shaken horizontally for 1 minute, and treated (twice for 3 seconds at 10\% intensity) with a Sonopuls UW 3100 ultrasonic probe (Bandelin Electronic GmbH, Berlin, Germany). After sedimentation of the glass beads for 1 minute, subsamples of $99 \mu \mathrm{L}$ were taken from the supernatant and stained with $1 \mu \mathrm{L}$ SYTO 13 (500 $\mu \mathrm{M}$; Thermo Fisher Scientific, Waltham, MA, USA) for 15 minutes. After individual calibration with an undyed subsample of $100 \mu \mathrm{L}$ of each sample, triplicates of bacterial cell samples were counted at $488 \mathrm{~nm}$ excitation with flow cytometry (FACScalibur; BD Biosciences, San Jose, CA, USA). Results of EPS and biomass analyses were correlated with the dry weight (DW) of the corresponding samples.

\section{Algal community composition}

Sediment/biofilm samples were fixed with Lugol's iodine $(2 \%)$ and analyzed to assess the development of the algal community derived from chlorophyll $a$ contents. For diatom determination, the organic content of the samples was removed by boiling in $\mathrm{H}_{2} \mathrm{O}_{2}(30 \%)$, followed by three washing steps with sterile filtrated, deionized water (Milli-Q). The diatom frustules were embedded in Naphrax (Northern Biological Supplies, Ipswich, UK). For species determination, 300 valves were identified ${ }^{32-34}$ at $1,000 \times$ magnification using an Avio microscope (Carl Zeiss Meditec AG, Jena,
Germany) with differential interference contrast and the relative abundance of each taxon recorded. Data were evaluated by calculation of the Shannon diversity index. ${ }^{35}$

\section{Bacterial community composition PCR}

DNA was isolated from the biofilm/sediment samples with a NucleoSpin kit for soil (Macherey and Nagel, Düren, Germany) according to the manufacturer's instructions. Bacterial 16S rRNA genes were amplified via polymerase chain reaction (PCR) assay using the universal primers $27 \mathrm{f}$ ( $5^{\prime}$-AGA GTT TGA TCM TGG CTC AG-3') and 517r (5'-ATT ACC GCG GCT GCT GG-3'). ${ }^{36,37}$ For subsequent denaturing gradient gel electrophoresis (DGGE) a GC clamp (5'-CGC CCG CCG CGC CCC GCG CCC GTC CCG CCG CCG CCC CCG CCC C-3') was attached to the primer 27f. Each PCR reaction $(25 \mu \mathrm{L})$ amplifying $15 \mathrm{ng}$ DNA consisted of $16.38 \mu \mathrm{L}$ sterile PCR water (Merck Millipore, Billerica, MA, USA), $2.5 \mu \mathrm{L}$ 10× PCR buffer (Qiagen, Venlo, Netherlands) provided by the enzyme manufacturer, $0.125 \mu \mathrm{L}$ deoxyribose nucleoside triphosphates $(200 \mu \mathrm{M}), 0.25 \mu \mathrm{L}$ of each primer $(40 \mu \mathrm{M})$, and $0.13 \mu \mathrm{L}$ Taq DNA polymerase $(5 \mathrm{U} / \mu \mathrm{L}$ HotStarTaq polymerase, Qiagen). Amplification was run in a GeneAmp PCR system 9700 (Thermo Fisher Scientific) as follows: 30 seconds at $94^{\circ} \mathrm{C}, 35$ cycles of 30 seconds at $94^{\circ} \mathrm{C}, 30$ seconds at $55^{\circ} \mathrm{C}$, and 60 seconds at $72^{\circ} \mathrm{C}$. The final extension lasted 7 minutes at $72^{\circ} \mathrm{C}$. The PCR products were loaded onto $1 \%$ agarose gels in TAE buffer $(\mathrm{pH} 8)$, stained with GelRed (GeneOn, Ludwigshafen, Germany), and studied under ultraviolet illumination $(600 \mathrm{~nm})$.

\section{DGGE}

DGGE was performed using a DCode system (Bio-Rad Laboratories, Hercules, CA, USA), as described by Muyzer et al: ${ }^{38}$ a 1.5 mm-thick vertical gel containing $7.5 \%$ (w:v) polyacrylamide (37.5:1 acrylamide:bis-acrylamide) with a linear denaturing gradient of urea and formamide (40\%$70 \%$ ) was loaded with similarly sized PCR products. After electrophoresis in TAE buffer ( $\mathrm{pH} 8.5$ ) for 17 hours at $70 \mathrm{~V}$ and $56^{\circ} \mathrm{C}$, gels were stained with GelRed for 15 minutes and analyzed with a Lumi-Imager F1 workstation (Hoffman-La Roche, Basel, Switzerland). DGGE banding-pattern analysis was based on images of each gel taken with a CCD camera system (Appligene Imager) and processed with Lumi Analyst 3.1 software. Range-weighted richness ( $R r)$, community dynamics, and functional organization (Fo) were calculated after processing with the programs GelCompar II and ImageJ, as described by Marzorati et al. ${ }^{39} \mathrm{Rr}$ values were derived from 
the number of DGGE bands and the stretch of gel covered by the fingerprint, reflecting the microbial diversity and capacity of the investigated system. While the community-dynamic value reflects the "rates of change" in the microbial community derived from moving-window analysis comparing consecutive DGGE bands, the Fo value is defined as the ratio between dominant and resilient microorganisms derived from Pareto-Lorenz evenness curves. ${ }^{40}$

\section{Clone libraries and sequencing}

Prominent DGGE bands were excised from GelRed-stained gels and reamplified via PCR using the same DGGE primers without GC clamps. A total of 73 DNA fragments of $540 \mathrm{bp}$ length were purified with the Wizard genomic DNApurification kit (Promega, Fitchburg, WI, USA). Cloning of the purified DGGE bands was performed using a Tops TA cloning kit (Thermo Fisher Scientific) with the pCR 4 Topo vector and one-shot chemically competent Escherichia coli cells, following the instructions of the manufacturer. Three to five clones per band were selected and grown overnight in $5 \mathrm{~mL}$ lysogeny broth containing $100 \mu \mathrm{g} / \mathrm{mL}$ ampicillin. The transformed $E$. coli clones were sent to GATC Biotech AG (Constance, Germany): after plasmid purification, the primers $\mathrm{M} 13$ forward and reverse were used to sequence-clone DGGE bands. Obtained sequences were manually edited in Chromas Lite (Technelysium, Brisbane, Australia), compared to sequences in the NCBI BLAST (Basic Local Alignment Search Tool) database, and aligned using the SINA aligner of ARB (version 5.2) software and the corresponding Silva SSU Ref 102 database. ${ }^{41}$

\section{Surface adhesiveness}

To assess biofilm stability, a modified magnetic particleinduction system ${ }^{42}$ was used, as described by Schmidt et al. ${ }^{26}$ Briefly, the adhesiveness of the biofilm surfaces was measured with an electromagnet with highly magnetizable $\mu$-metal core. In total, 24 replicates per sampling day were measured by attracting ferromagnetic particles from the biofilm surface. The adhesion force of the analyzed surface is equivalent to the magnetic force required to retrieve the ferromagnetic particles, and can be calculated from the applied electric current (amperage). Herein, the term "biofilm adhesiveness" is used as a proxy for biofilm stability, as the exact correlation between the measured adhesion force and the erosion resistance of the biofilm is still being researched.

\section{Statistics}

Statistical analysis was performed with Analyze-It225 (1.0.5.0.) software. Shapiro-Wilk tests $(95 \%$ CI) were applied to check for normal distribution of the data sets. One-way analysis of variance ( $95 \%$ CI, $\chi^{2}$ approximation, Tukey's error protection) was performed for comparison of normally distributed data sets. Otherwise, Kruskal-Wallis tests (KWTs; $\chi^{2}$ approximation, Bonferroni correction for ties) were conducted. Correlations of different parameters were tested by calculating Spearman's rank-correlation coefficients.

\section{Results}

\section{Biofilm parameters}

Although matured biofilms cultivated under medium BSS displayed maximal mean values for chlorophyll $a$ (5.9 \pm 3.6 $\mu \mathrm{g} / \mathrm{gDW})$ and $\mathrm{BCC}\left(6.1 \pm 2.7 \times 10^{7} \mathrm{gDW}\right)$, the different levels of BSS did not have a statistically significant impact on bacterial or algal biomass (KWT; BCC, $\mathrm{n}=36, P=0.2329$; chlorophyll $a, \mathrm{n}=85, P=0.1948)$. However, bacterial communities were clearly influenced by BSS, as Rr was significantly lowest under the highest BSS (KWT, $\mathrm{n}=84 ; P<0.0001$ ), while dynamics in the community increased significantly with BSS (KWT, $\mathrm{n}=66 ; P<0.0001$ ). Furthermore, the influence of BSS upon biofilm development became clear by a strong trend indicating decreasing biofilm adhesiveness with increasing BSS (KWT, $\mathrm{n}=85 ; P=0.05124$ ). Detailed information about the influence of the different applied levels of BSS during biofilm cultivation upon all assessed biofilm parameters can be seen in Table 3. Biofilms cultivated under different levels of LI displayed significant differences in various parameters (Table 4): mean contents of EPS carbohydrates and proteins were significantly lowest in matured biofilms grown under no LI (KWT; EPS carbohydrates, $\mathrm{n}=87, P=0.0006$; EPS proteins, $\mathrm{n}=87, P=0.0082$ ). Likewise, algal biomass (KWT, $\mathrm{n}=87 ; P<0.0001)$ and bacterial $\mathrm{Rr}(\mathrm{KWT}, \mathrm{n}=84 ; P<0.0001)$ were both significantly lowest in biofilms developing under no LI, while dynamics were highest (KWT, $\mathrm{n}=68 ; P=0.0158$ ), and functional organization of the bacterial community under no LI remained approximately unchanged throughout the experiments. In contrast, bacterial communities displayed increasing and significantly higher mean values of specialization in matured biofilms when developing under medium and highest LI (KWT, $\mathrm{n}=82 ; P=0.0026)$.

\section{Biofilm adhesiveness}

While initial levels of adhesiveness were very similar in all early biofilm stages (mean values of approximately 70 $\mathrm{mA}$ ), the highest mean adhesiveness in late biofilm stages was detected in biofilms grown under the highest level of LI $(1,001.7 \pm 994.1 \mathrm{~mA})$. With a value of $810.2 \pm 1044.6 \mathrm{~mA}$, the mean adhesiveness of biofilms cultivated under the lowest 
Table 3 Comparison of biofilms grown under different levels of BSS (means \pm SD)

\begin{tabular}{|c|c|c|c|c|c|c|c|}
\hline \multirow[t]{2}{*}{ Biofilm parameter } & \multicolumn{2}{|c|}{ Minimal BSS } & \multicolumn{2}{|c|}{ Medium BSS } & \multicolumn{2}{|c|}{ Maximal BSS } & \multirow{2}{*}{$\begin{array}{l}\text { Difference } \\
\text { between } \\
\text { treatments }\end{array}$} \\
\hline & $\begin{array}{l}\text { Early } \\
\text { Day 0-18 }\end{array}$ & $\begin{array}{l}\text { Late } \\
\text { Day 2I-35 }\end{array}$ & $\begin{array}{l}\text { Early } \\
\text { Day 0-18 }\end{array}$ & $\begin{array}{l}\text { Late } \\
\text { Day 2I-35 }\end{array}$ & $\begin{array}{l}\text { Early } \\
\text { Day 0-18 }\end{array}$ & $\begin{array}{l}\text { Late } \\
\text { Day 2I-35 }\end{array}$ & \\
\hline \multicolumn{8}{|l|}{ EPS } \\
\hline \multicolumn{8}{|l|}{$\left(\mu g g W^{-1}\right)$} \\
\hline Proteins ( $\mu \mathrm{g} g \mathrm{gW}^{-1}$ ) & $10.2 \pm 9.6$ & $33.1 \pm 10.2$ & $13.4 \pm 6.3$ & $31.5 \pm 13.2$ & $4.5 \pm 3.2$ & $29.8 \pm 8.0$ & $S$ \\
\hline \multicolumn{8}{|l|}{ Biomass } \\
\hline $\begin{array}{l}\text { Chlorophyll } a \\
\left(\mu g g^{-1}\right)\end{array}$ & $0.3 \pm 0.3$ & $6.9 \pm 6.5$ & $0.5 \pm 0.5$ & $5.9 \pm 3.6$ & $0.2 \pm 0.2$ & $3.6 \pm 3.0$ & $\mathrm{~N}$ \\
\hline Bacterial cells $\left({ }^{*} 10^{7} \mathrm{gDW}^{-1}\right)$ & $1.8 \pm 2.3$ & $4.7 \pm 3.7$ & $1.6 \pm 1.9$ & $6.1 \pm 2.7$ & $0.6 \pm 0.6$ & $4.6 \pm 1.7$ & $N$ \\
\hline \multicolumn{8}{|l|}{ Bacterial community } \\
\hline Range weighted richness & $6.1 \pm 1.8$ & $9.5 \pm 6.2$ & $8.2 \pm 2.2$ & $10.9 \pm 5.0$ & $4.7 \pm 1.2$ & $4.8 \pm 2.3$ & $S$ \\
\hline Functional organization & $41.6 \pm 7.0$ & $68.0 \pm 11.4$ & $59.3 \pm 7.0$ & $67.9 \pm 7.3$ & $59.7 \pm 5.1$ & $61.4 \pm 12.0$ & $S$ \\
\hline Dynamics & $10.0 \pm 5.1$ & $17.3 \pm 3.3$ & $18.3 \pm 9.2$ & $21.2 \pm 9.1$ & $26.6 \pm 18.8$ & $32.9 \pm 15.0$ & $S$ \\
\hline \multicolumn{8}{|l|}{ Diatom community } \\
\hline Shannon index & $1.8 \pm 0.1$ & $1.7 \pm 0.8$ & $3.1 \pm 0.2$ & $2.8 \pm 0.8$ & $2.6 \pm 0.1$ & $2.1 \pm 0.3$ & $\mathrm{~N}$ \\
\hline Evenness & $0.5 \pm 0.1$ & $0.5 \pm 0.2$ & $0.8 \pm 0.1$ & $0.8 \pm 0.2$ & $0.8 \pm 0.1$ & $0.7 \pm 0.1$ & $\mathrm{~N}$ \\
\hline \multicolumn{8}{|l|}{ Biofilm stability } \\
\hline Adhesiveness (mA) & $72.9 \pm 47.3$ & $810.3 \pm 1044.6$ & $73.5 \pm 50.4$ & $435.0 \pm 316.7$ & $84.8 \pm 55.4$ & $340.6 \pm 270.8$ & $\mathrm{~N}$ \\
\hline
\end{tabular}

Note: Data presented as mean \pm SD.

Abbreviations: BSS, bed shear stress; EPS, extracellular polymeric substances; DW, dry weight; N, no significant difference detectable; S, significant difference observed.

Table 4 Comparison of biofilms cultivated under different levels of LI (means \pm SD)

\begin{tabular}{|c|c|c|c|c|c|c|c|}
\hline \multirow[t]{2}{*}{ Biofilm parameter } & \multicolumn{2}{|c|}{ Minimal LI } & \multicolumn{2}{|c|}{ Medium LI } & \multicolumn{2}{|c|}{ Maximal LI } & \multirow{2}{*}{$\begin{array}{l}\text { Difference } \\
\text { between } \\
\text { treatments }\end{array}$} \\
\hline & $\begin{array}{l}\text { Early } \\
\text { Day 0-18 }\end{array}$ & $\begin{array}{l}\text { Late } \\
\text { Day 21-39 }\end{array}$ & $\begin{array}{l}\text { Early } \\
\text { Day 0-18 }\end{array}$ & $\begin{array}{l}\text { Late } \\
\text { Day 21-39 }\end{array}$ & $\begin{array}{l}\text { Early } \\
\text { Day 0-18 }\end{array}$ & $\begin{array}{l}\text { Late } \\
\text { Day 21-39 }\end{array}$ & \\
\hline \multicolumn{8}{|l|}{ EPS } \\
\hline Carbohydrates $\left(\mu \mathrm{g} \mathrm{gDW}^{-1}\right)$ & $|5.7 \pm 7|$. & $10.3 \pm 4.3$ & $18.8 \pm 9.1$ & $23.6 \pm 7.6$ & $10.7 \pm 5.8$ & $20.3 \pm 13.4$ & $S$ \\
\hline Proteins $\left(\mu \mathrm{g} g \mathrm{gW}^{-1}\right)$ & $4.0 \pm 2.1$ & $6.1 \pm 0.9$ & $2.7 \pm 1.5$ & $8.4 \pm 3.1$ & $3.9 \pm 3.5$ & $10.2 \pm 6.1$ & S \\
\hline \multicolumn{8}{|l|}{ Biomass } \\
\hline Chlorophyll a ( $\left.\mu \mathrm{g} g \mathrm{gW}^{-1}\right)$ & $0.0 \pm 0.0$ & $0.1 \pm 0.0$ & $0.1 \pm 0.1$ & $2.4 \pm 2.9$ & $0.3 \pm 0.2$ & $3.7 \pm 4.4$ & S \\
\hline Bacterial cells $\left(* 10^{7} \mathrm{gDW}^{-1}\right)$ & $0.8 \pm 0.3$ & $1.3 \pm 0.7$ & $0.4 \pm 0.3$ & $3.0 \pm 0.9$ & $1.5 \pm 1.0$ & $4.3 \pm 4.0$ & S \\
\hline \multicolumn{8}{|l|}{ Bacterial community } \\
\hline Range weighted richness & $5.4 \pm 0.9$ & $4.3 \pm 2.8$ & $31.2 \pm 2.9$ & $38.6 \pm 11.1$ & $32.4 \pm 1.0$ & $39.5 \pm 9.0$ & S \\
\hline Functional organization & $50.6 \pm 2.9$ & $50.9 \pm 4.1$ & $50.2 \pm 4.5$ & $56.8 \pm 5.5$ & $52.2 \pm 2.2$ & $64.9 \pm 4.6$ & $S$ \\
\hline Dynamics & $16.0 \pm 5.2$ & $15.6 \pm 3.4$ & $10.3 \pm 6.1$ & $4.9 \pm 2.6$ & $8.7 \pm 1.4$ & $14.7 \pm 9.4$ & S \\
\hline \multicolumn{8}{|l|}{ Diatom community } \\
\hline Shannon Index & $1^{\#}$ & l & $3.3 \pm 0.2$ & $1.0 \pm 0.1$ & $2.7 \pm 0.2$ & $1.4 \pm 0.2$ & $\mathrm{~N}$ \\
\hline Evenness & I & l & $0.9 \pm 0.1$ & $0.4 \pm 0.2$ & $0.7 \pm 0.1$ & $0.5 \pm 0.1$ & $\mathrm{~N}$ \\
\hline \multicolumn{8}{|l|}{ Biofilm stability } \\
\hline Adhesiveness ( $\mathrm{mA}$ ) & $71.2 \pm 11.0$ & $73.6 \pm 28.4$ & $55.5 \pm 12.7$ & $675.9 \pm 837.8$ & $58.0 \pm 17.3$ & $1001.7 \pm 994.1$ & S \\
\hline
\end{tabular}

Notes: \#Under minimal illumination, no significant algal development could be observed. Data presented as mean \pm SD.

Abbreviations: LI, light intensity; EPS, extracellular polymeric substances; DW, dry weight; N, no significant difference detectable; S, significant difference observed.

BSS was insignificantly lower. Furthermore, no LI was the only boundary condition where no significant increase in biofilm adhesiveness was detected (Figure 2).

\section{EPS and microbial biomass}

Comparison of different levels of BSS made it clear that early biofilm stages under the highest level of BSS displayed lower mean EPS carbohydrate and protein contents. However, these differences were mitigated in late biofilms. The reverse development was detected when comparing different levels of LI: although all early biofilms had a similar content of carbohydrates and proteins in colloidal EPS, late biofilms cultivated under no LI had significantly lowest mean values of EPS carbohydrates and proteins contents (Figure 3 ). 

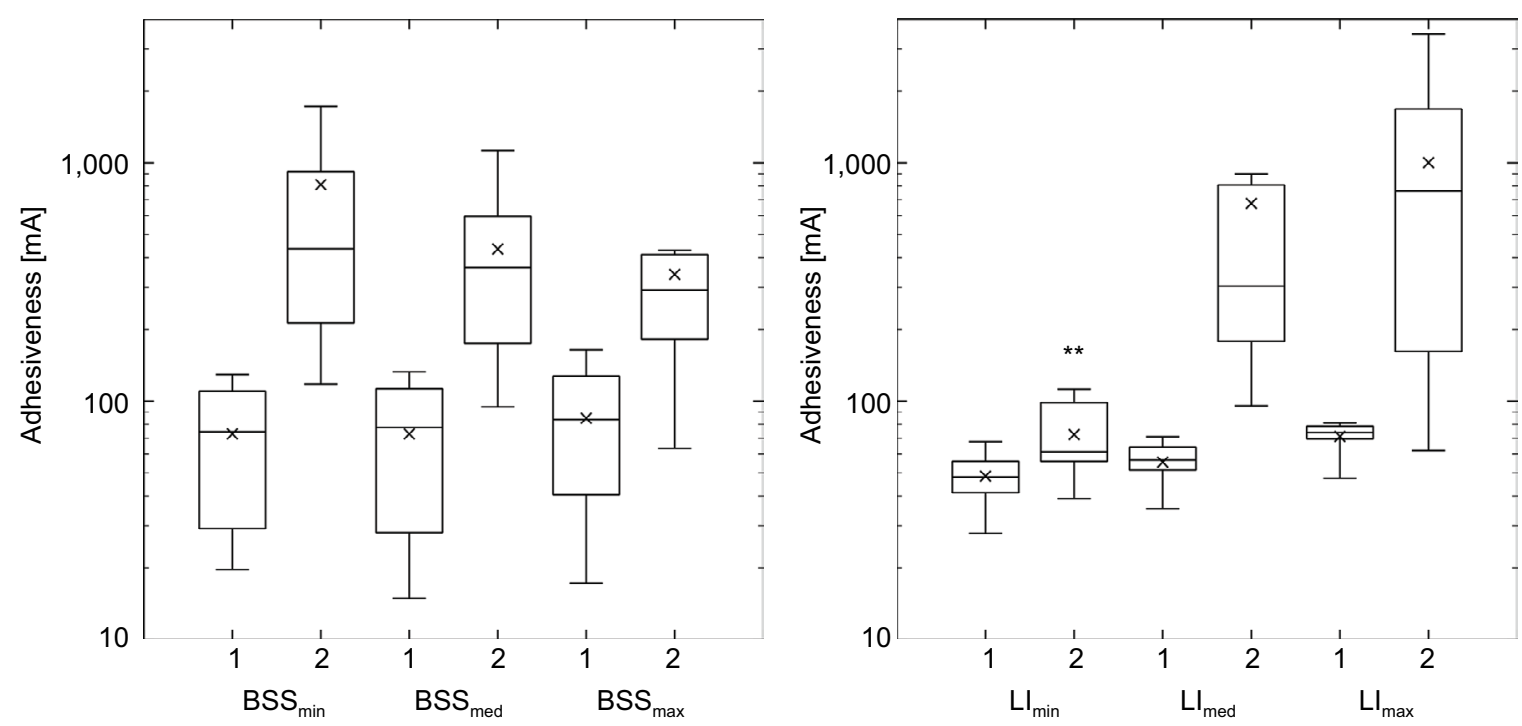

Figure 2 Adhesiveness of early ( $\mathrm{I}$ ) and late (2) biofilm stages.

Notes: Left, under different levels of BSS; right, under different levels of Ll; with logarithmic ordinate). ${ }^{* *} P<0.000$ I for same biofilm stage under other boundary conditions. Abbreviations: BSS, bed shear stress; LI, light intensity.
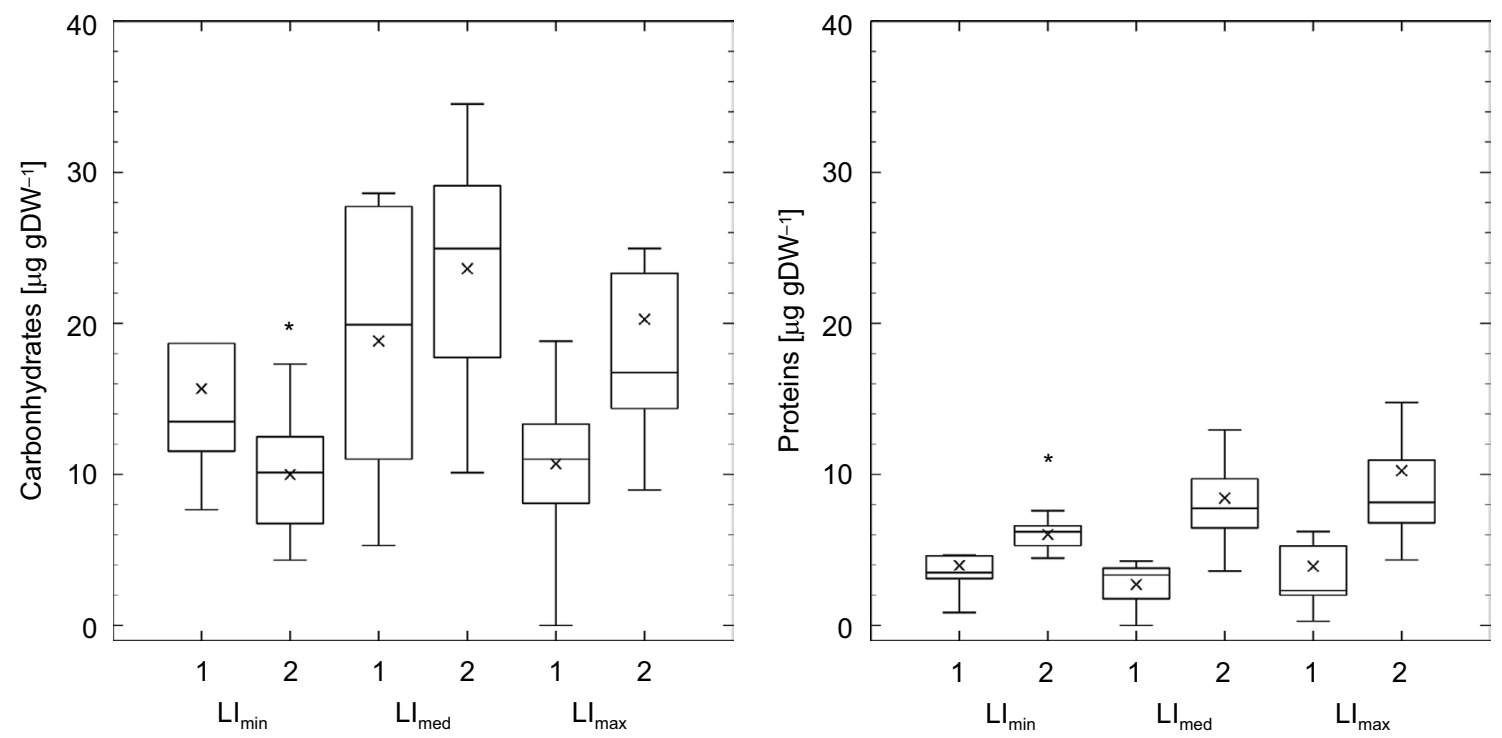

Figure 3 Content of EPS components of early (I) and late (2) biofilm stages under different levels of LI.

Notes: Left, EPS carbohydrates; right, EPS proteins. $* P<0.05$ for same biofilm stage under other boundary conditions.

Abbreviations: EPS, extracellular polymeric substances; LI, light intensity.

Under different levels of BSS, development of bacterial and algal biomass was very similar to observed changes in EPS components. Early biofilm stages that developed under the highest flow velocity displayed lower mean EPS contents than biofilms under lower levels of BSS. In late biofilms, bacterial and algal biomass were very similar under all flow velocities. However, biofilms under maximal BSS mitigated the difference in BCC more than the differences in chlorophyll $a$ content (Figure 4). In contrast to this, matured stages of biofilms cultivated under medium or highest LI showed significantly higher bacterial and algal biomass than biofilms grown under no LI.

\section{Bacterial ecology}

The $\mathrm{Rr}$ of biofilms grown under the lowest and medium BSS displayed increasing mean values, while the mean $\mathrm{Rr}$ of biofilms cultivated under the highest level of BSS stayed approximately constant at a significantly lower level (KWT, $\mathrm{n}=84 ; P<0.0001)$. Parallel to this development, the mean $\mathrm{Rr}$ of biofilms developing under medium and highest LI increased 

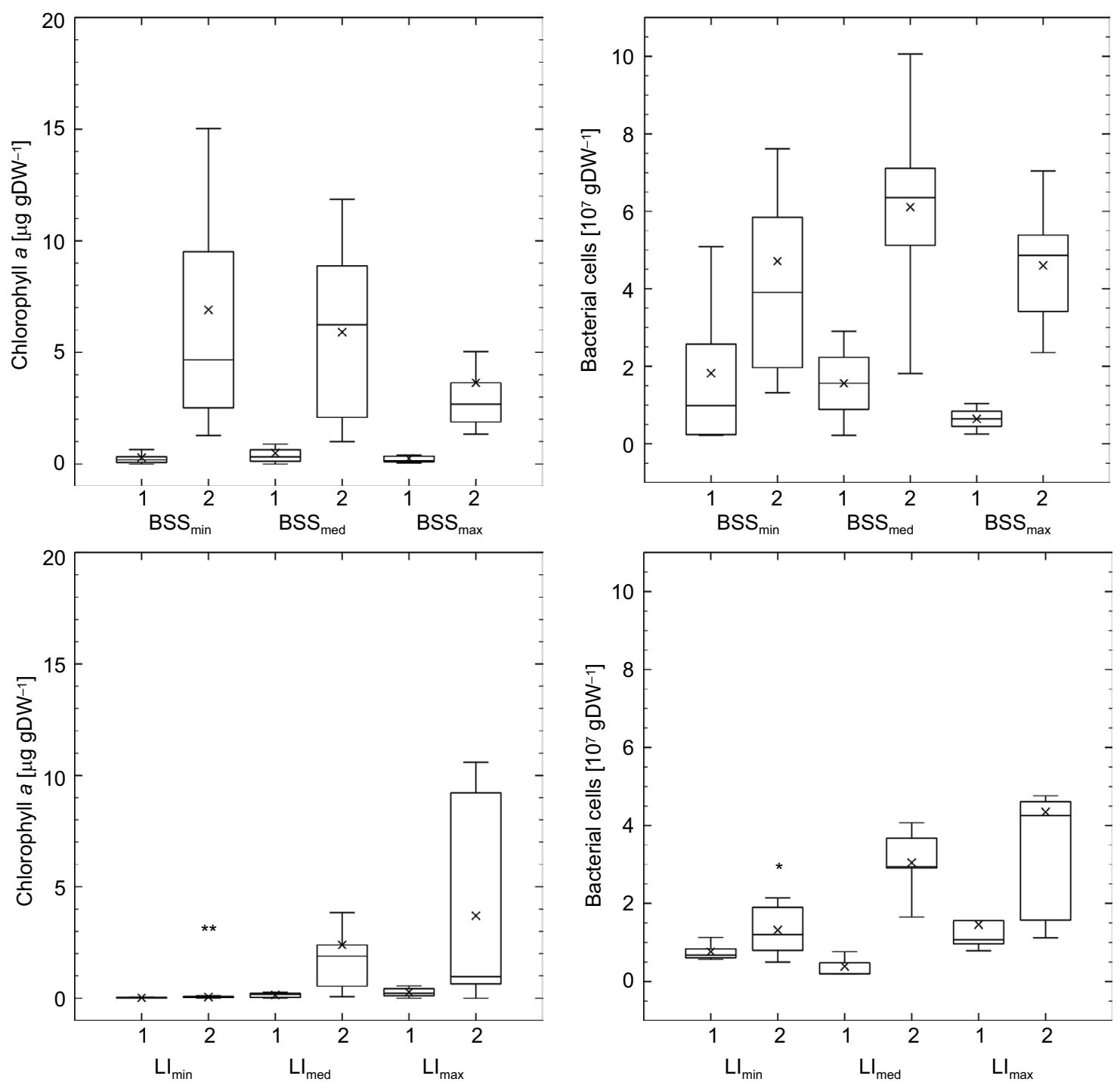

Figure 4 Microbial biomass of early (I) and late (2) biofilm stages.

Notes: Upper left, algal biomass under different levels of BSS; upper right, bacterial biomass under different levels of BSS; lower left, algal biomass under different levels of $\mathrm{LI}$; lower right, bacterial biomass under different levels of $\mathrm{LI}$. ${ }^{*} * \mathrm{P}<0.000 \mathrm{I}, * \mathrm{P}<0.05$ for same biofilm stage under other boundary conditions.

Abbreviations: BSS, bed shear stress; LI, light intensity.

over time, while the mean values of biofilms grown under no LI were significantly lower (KWT, $\mathrm{n}=84 ; P<0.0001)$ and decreasing over time (Figure 5). The mean Fo in early biofilms was significantly lower under the lowest BSS than under medium or highest BSS (KWT, $\mathrm{n}=78 ; P=0.0014)$, indicating a higher degree of functional redundancy among bacteria under minimal BSS. However, this mean value significantly increased over time (KWT, $\mathrm{n}=96 ; P<0.001$ ), resulting in no significant difference in mean Fo in late biofilms under the different levels of flow velocity (KWT, $\mathrm{n}=84 ; P=0.1879$ ). No LI resulted in constant Fo, while medium and highest LI led to an increase in Fo over time. As a consequence, the significantly highest mean Fo was detected in late biofilms under the highest LI (KWT, $\mathrm{n}=114 ; P<0.0001)$. While no clear trend was observed in biofilms under different levels of LI (stable dynamics under no LI, decreasing dynamics under medium LI, and increasing dynamics under highest LI), a clear correlation was indicated under different levels of BSS: mean dynamics significantly raised with increasing BSS (KWT, $\mathrm{n}=66 ; P<0.0001)$.

\section{Microbial community \\ Bacteria}

Analysis of the 211 prominent bacterial DGGE bands/ sequences yielded 77 different bacterial species. As described by Schmidt et al, ${ }^{26}$ the influence of seasonality is of great importance for the composition of microbial communities and resulting biofilm stability. Detailed information about 

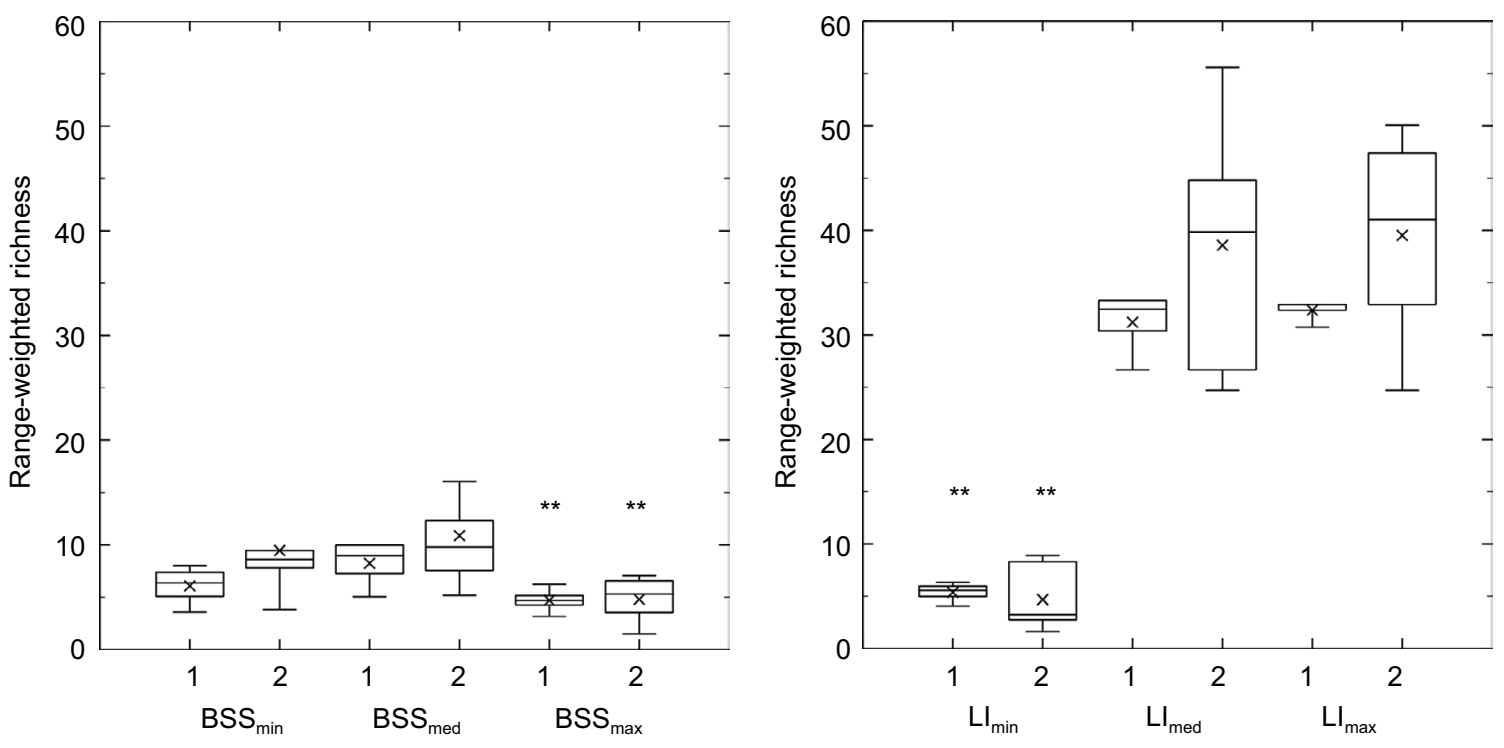

Figure 5 Range-weighted richness of early (I) and late (2) biofilm stages.

Notes: Left, under different levels of BSS; right, under different levels of LI. $* * P<0.000 \mathrm{I}$ for same biofilm stage under other boundary conditions.

Abbreviations: BSS, bed shear stress; LI, light intensity.

the seasonality within the bacterial biofilm community will be published elsewhere, as this study focused on the spring experiments performed that displayed the highest stabilizing potential. Examples of detected typical freshwater species during spring were Aquabacterium spp. ${ }^{43}$ Brevundimonas diminuta,${ }^{44}$ and Gemmatimonas phototrophica. ${ }^{45,46}$ Besides these ubiquitous occurring microorganisms, several bacterial species were identified that were independent of LI. However, four species dominated in biofilms grown under high LI: Rubrivivax gelatinosus ${ }^{47}$ and Rhodoferax saidenbachen$\operatorname{sis}^{48}$ in early development stages and Neosynechococcus sphagnicola ${ }^{49}$ and Leptolyngbya spp. ${ }^{50}$ in matured biofilms. In comparison to this, different levels of SS displayed no significant influence upon bacterial community composition, with Pseudomonas taiwanensis constituting the only exception, with a stronger appearance in biofilms cultivated under high flow velocity.

\section{Diatoms}

In total, 13 diatom genera were present in relative abundance greater than 3\% in the investigated biofilms. Among these, four - Fragilaria (F.), Sellaphora (S.), Nitzschia (N.), and Achnanthidium (A.) - appeared to dominate the biofilms in variable abundance ratios. Biofilms cultivated under the lowest BSS were clearly dominated by Achnanthidium minutissimum (mean relative abundance of $52 \% \pm 3.6 \%$ in early biofilms and $59.4 \% \pm 4.2 \%$ in late biofilms). This strong dominance was also reflected by minimal mean diversity and evenness (Table 3). Under increasing BSS, the genus Nitzschia - mainly N. fonticola, $N$. abbreviata and $N$. dissipata - increased proportionally in matured biofilms, as a comparison of their cumulative mean relative abundances clearly showed: $9.9 \% \pm 0.2 \%$ in biofilms cultivated under the lowest level of BSS, $24.9 \% \pm 3.3 \%$ in biofilms grown under medium BSS, and $40.8 \% \pm 3.5 \%$ in biofilms developed under the highest BSS. Besides this, Sellaphora seminulum reached a mean relative abundance of $22.1 \% \pm 3.3 \%$, which was similar to the members of the genus Nitzschia in matured biofilms under medium BSS (see Figure 6).

The most apparent impact of the different applied levels of LI was the absence of algal development under no LI. Furthermore, in contrast to biofilms cultivated under different levels of BSS, members of Nitzschia were less dominant. Late biofilm stages were always dominated by a variable combination of $A$. minutissimum, $S$. seminulum, and members of Fragilaria, mainly F. construens and F. pararumpens: A. minutissimum clearly dominated biofilm grown under medium LI (mean relative abundance of $65.2 \% \pm 5.1 \%$ ) while $S$. seminulum showed mean relative abundance of $24.7 \% \pm 3.3 \%$. In late biofilms that grew under the highest LI, A. minutissimum and F. pararumpens both constituted the majority of the diatom community $(44.6 \% \pm 2.7 \%$ and $37.2 \% \pm 3.3 \%$, respectively). The increasing dominance of a few species was reflected by decreasing diversity (Shannon index) and evenness of diatom communities under medium and the highest LI (Table 4). 


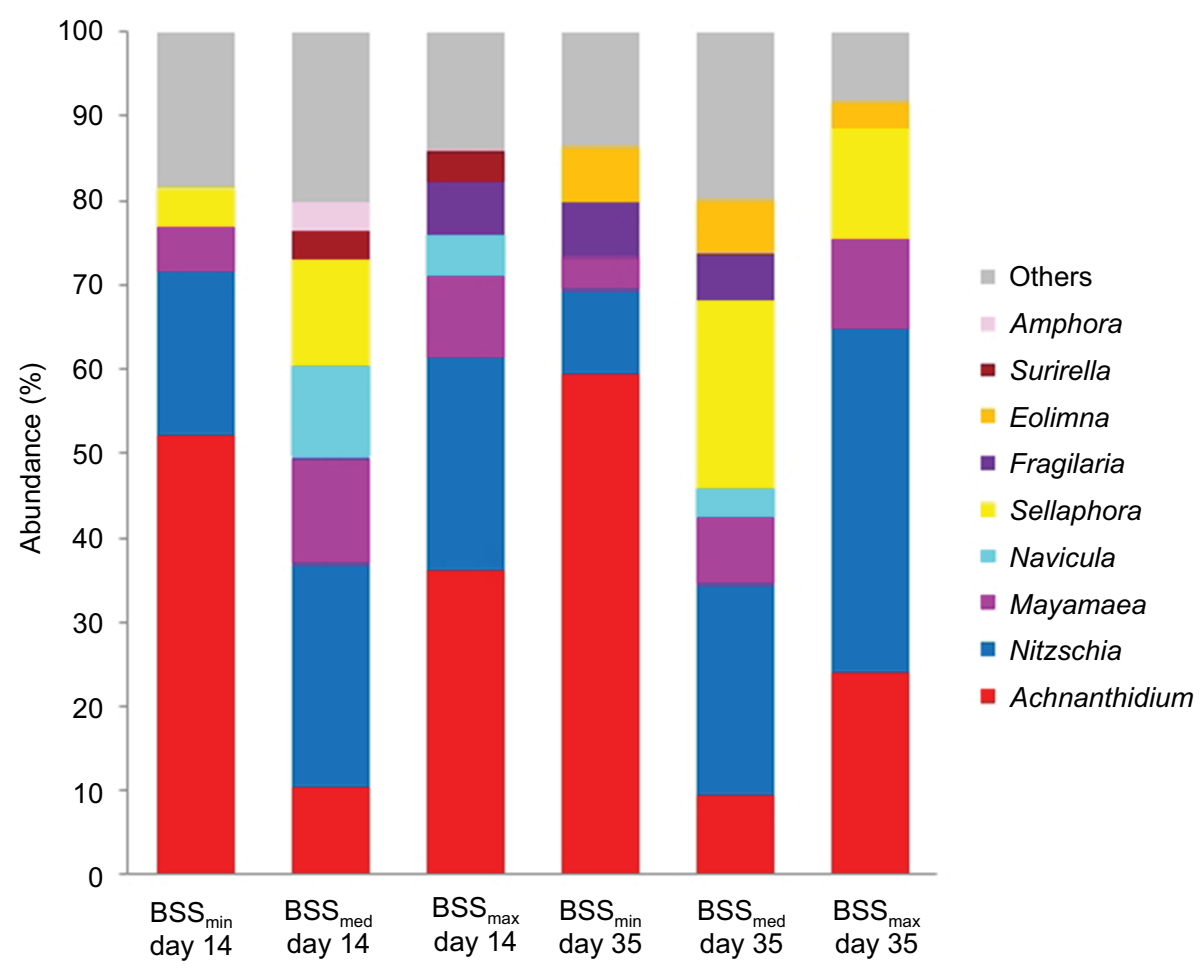

Figure 6 Composition of early (day 14) and late (day 35) diatom communities.

Notes: Under different levels of BSS during May 2013, displayed as relative abundance. Others are genera with relative abundance $<3 \%$. Abbreviation: BSS, bed shear stress.

\section{Discussion}

\section{Impact of hydrodynamic regime}

Due to the high importance of a fully developed, homogenous turbulence over the test section of the flumes, the experimental setup was designed and constructed with the know-how of engineering science. Generally, hydrodynamics can have a major, very visible influence upon benthic microbial communities. As an example, different structures in rivers that influence BSS have been demonstrated to have massive impact on the microbial composition of biofilms, eg, recessed areas were shown to promote the growth of long filamentous chlorophytes, which were not abundant in exposed areas..$^{51}$ This example demonstrates the great potential of hydrodynamic boundary conditions to shape living conditions of biofilm microorganisms. On one hand, the biofilm is diffusion-limited in its uptake of nutrients, and increased turbulence can reduce the thickness of the diffusive boundary layer. This can accelerate mass transfer from and toward the overlaying water column, ${ }^{52,53}$ especially into and within biofilm voids. ${ }^{54}$ This diffusion limitation may be one reason that very thick biofilm ${ }^{54}$ or biofilm developing in waters with low flow velocity tends to develop filamentous structures called "streamers", which undulate to increase turbulence and thereby the transport rate of nutrients to the biofilm cells. ${ }^{55,56}$ On the other hand, high levels of BSS on the sediment and biofilm surface can constitute a stressor for biofilm formation. Shear force determines bacterial detachment, ${ }^{57}$ and has been shown to promote biofilm erosion/ sloughing ${ }^{58}$ but it also shapes the community structure of microbes, including algae and protists. ${ }^{59,60}$ In addition, high levels of BSS can strongly delay the formation of natural complex biofilms on fresh uncolonized sediment, which was also reported by Coundoul et al. ${ }^{61}$ One possible explanation may be the impairment of bacterial settlement and thus the initial phase of biofilm formation. ${ }^{62}$ Established bacterial biofilms may be able to react to present levels of BSS and adapt their morphology ${ }^{63,64}$ However, if the initial bacterial settlement is affected by high BSS forces, the next succession steps in biofilm formation can be impeded too. A reason for this delay in biofilm formation may be found in a variety of complex interactions among bacteria and algae during the nascent stages of a biofilm. The initial development of a bacterial biofilm as a "conditioning layer" on the sediment has been described as essential for subsequent settlement of larger microbes such as diatoms. ${ }^{7,65}$ Consequently, impairment of the bacterial community can also strongly influence the community composition of the diatom community in a developed biofilm. ${ }^{66}$

In consideration of these ambivalent impacts, a medium level of flow velocity appears to constitute an optimal 
situation for biofilm growth (sufficient nutrient supply and tolerable shear forces). Interestingly, bacteria seem to be less susceptible to BSS than diatoms (decrease in mean chlorophyll $a$ contents with increasing flow velocity $\sim 50 \%$ compared to approximately stable BCC under the highest level of BSS). Besides the clear fact that bacteria possess a much smaller windage than significantly bigger diatoms, a possible explanation may be increasing contact events of cells within the substrate with growing turbulence and flow velocity. In particular, first contact, number of contact events, and substrate characteristics are of great importance as the microbial cell itself first reacts as an inert particle, ${ }^{67}$ while near-surface forces, such as Brownian motion, can augment surface drag to the substrate. ${ }^{68}$ However, within seconds after contact with the substrate, bacterial cells can initiate a series of very fast and short reversible bindings, which apparently trigger irreversible binding to the surface. ${ }^{69}$ In this transition process of reversible-irreversible binding, bacterial flagella play an essential role as an instrument for bacteria actively to control attachment through rapid changes in genetic and metabolic pathways. ${ }^{70-72}$ This influence of flagella as important components in active attachment was described by Gu et $\mathrm{al},{ }^{73}$ who demonstrated that flagella response on microscale topography of the substrate constituted a driving factor for the orientation of the attached cell. When single cells are irreversibly attached to the surface and start to proliferate, their produced EPS augments the development of cell-cell adhesiveness, which can be even higher than the adhesion forces between cells and the substrate. ${ }^{74}$

\section{Effects of light intensity}

In contrast to the effects of BSS, the influence of LI and nutrient availability upon biofilm development is rather complex, because these two parameters cannot be regarded strictly separated, as light is the primary energy source for autotrophic organisms and their photosynthesis is directly linked to the growth in biomass and the uptake of nutrients. ${ }^{75-77}$ Other studies $^{78,79}$ have emphasized that LI is the most important driving factor for the development of the algal community structure, even more important than nutrient (phosphorus) limitation or the effect of grazing. Although this was supported by Zippel and Neu, ${ }^{80}$ microalgae are not the only key functional players. The complex interactions between autotrophic and heterotrophic microbes have to be taken into account as they shape the overall biofilm system. As already described, pioneering bacteria may be crucial for diatom settlement. Besides the complex competition for nitrogen and phosphorus between diatoms and bacteria, the amount of available organic carbon apparently strongly affects the entire biofilm food web. ${ }^{81}$ Recent studies have given insights into highly specialized EPS utilization by bacteria ${ }^{82}$ and discovered a strong regulatory role of these EPSs produced by diatoms upon bacterial development and activity. ${ }^{83}$

In the context of nutrient limitation, the morphology of the microbes can be a decisive factor. As an example, erected microalgae species can access nutrients from the water column overlying the nutrient-depleted periphyton, while microalgae that live adnately to the surface (such as diatoms) might have limited nutrient access. ${ }^{84-87}$ Some diatom species adapt to this disadvantage by faster reproduction to colonize new habitats very quickly, before they are suppressed by later successional stages that are more competitive ${ }^{88}$ Other diatom species are able to avoid suppression via the ability for relatively fast migration. ${ }^{89}$ These different lifestyles and attachment forms may have an essential impact upon overall biofilm stability, since flatly attaching microalgae species have been shown to exhibit significantly greater resistance to mechanical forces than erected specimens. ${ }^{90}$ Moreover, the movement of a great fraction of biofilm diatoms through the matrix might have a destabilizing effect. ${ }^{26}$ Together with the high complexity of the constantly changing and adapting biofilm community, the great importance of the temporal scale becomes clear, as different organisms may be dominant at different points in time. This is the reason for the high temporal resolution during sampling, which allows detailed insight into the microbial community.

With regard to cultivation conditions in the flumes, nutrient levels in the water taken from the River Enz were constantly low to moderate during the course of the year. Therefore, erected microalgae species might have had an advantage after long biofilm development. However, during spring, when biostabilization was maximal, pioneer diatoms were dominant in the river water, which is a result of natural seasonal succession in the river. ${ }^{32}$ In addition, these early successional stages, such as the permanently attaching, relatively small A. minutissimum, had a competitive advantage on the fresh, uncolonized sediment surfaces, due to their faster reproduction, and in higher flow regimes, due to their small windage and strong attachment. Therefore, especially during spring and in the observed period during the experiments, early successional stages had all the prerequisites to dominate the diatom community before later successional stages could establish dominance. The fact that relatively few diatom species were dominant throughout the experiments might have been due to the experimental setup as a closed system without the addition of new fresh river water during running 
experiments. Another explanation might be nutrient limitation, as suggested by the findings of Law et al, ${ }^{91}$ who reported significantly lower diversity of the diatom community under oligotrophic conditions than in eutrophic rivers. This nutrient limitation was stated to be more important than flow velocity or grazing. Furthermore, this might be one reason for the dominance of the bacterial community by Leptolyngbya, whose ability to fixate great amounts of atmospheric nitrogen $^{92}$ could have resulted in a decisive competitive advantage compared to other autotrophic microorganisms.

\section{Role of microorganisms in biofilm matrix}

All bacterial species dominant in maximal stable biofilms had at least one of two common features: they were either phototrophic and/or had very versatile metabolisms. Besides the two cyanobacteria of the genera Leptolyngbya and Pseudanabaena, Rhodobacter capsulatus was shown to be capable of anoxic photosynthesis, nitrogen fixation, and various other metabolic pathways, including different types of respiration. ${ }^{93}$ In addition, $R$. gelatinosus has been described as a very quickly growing facultative photoheterotrophic microorganism. ${ }^{47}$ Paracoccus aminophilus and $R$. saidenbachensis can be considered very adaptable microorganisms with a broad range of different respiration pathways ${ }^{94}$ and the ability to utilize various secondary algal metabolites, such as sugar alcohols, ${ }^{48}$ which can be considered constantly present in the EPS matrix, due to secretion by algal cells or as a result of cell death and lysis. This metabolic versatility might be an essential prerequisite for these microbes to utilize different niches, eg, gradient zones, in the biofilm system, which become increasingly complex due to diatom development. In this context, it is interesting to note that $R$. gelatinosus apparently dominated biofilms developing under high LI up to a point where diatoms proliferated in the system. In late biofilm stages, $R$. gelatinosus was apparently suppressed, which was clearly visible on DGGE fingerprints. This replacement may have been a result of the increasing competition for light as the primary energy source, due to the multiplying diatoms and other phototrophic bacteria like the detected cyanobacteria. However, besides other bacterial species, $R$. gelatinosus might play an essential role in conditioning the sediment surface, facilitating subsequent diatom settlement and development, as described for other heterotrophic bacteria. ${ }^{65}$ Moreover, the fast growth and potential for high EPS production of $R$. capsulatus and $P$. aminophilus ${ }^{95-97}$ may lead to a solid biofilm fundament tightly attached to the sediment grains, especially in crucial early developmental stages. This could be of major structural importance for the overall biofilm system and lead to higher biofilm stability. Considering these structural aspects, the two detected dominant cyanobacteria might also be of high relevance, as they form long filaments up to $5 \mathrm{~mm}$ in length. ${ }^{50}$ On one hand, these extended chains of single cells constitute an option to increase micro turbulence and availability of nutrients. On the other hand, these fibers can act as anchor points for settling cells and can be linked and tangled up, which can increase the stability of the biofilm network.

In contrast to biofilms displaying maximal stability, biofilms with low biostabilization capacity were dominated by bacteria of the genera Caulobacter or Pseudomonas, and exhibited very high motility. This feature is essential for fast colonization of favorable substrates and new nutrient resources. ${ }^{98}$ However, the lifestyle of Caulobacter vibrioides might decrease overall biofilm stability, as the anisomorphic reproduction cycle with staked and swarmer cells ${ }^{99}$ can be assumed to lead to a steadily shifting, comparably unstable cover with bacterial cells, as opposed to a colonization by immotile bacteria, such as $P$. aminophilus, which forms stable clusters of cells. ${ }^{94}$ The swimming behavior of the two dominant monotrichous $P$. fluorescens and P. taiwanensis has been described as very similar to Caulobacter specimens. ${ }^{100}$ However, in contrast to Caulobacter, for Pseudomonas the flagellum is of major importance for surface adhesion as the initial step of biofilm formation. ${ }^{101}$ Moreover, Decoin et $\mathrm{al}^{102}$ demonstrated an expressional link between flagellum compounds, such as flagellin, and the production of antimicrobial agents, and suggested that parallel motility and antibiotic production enhances competitiveness. The well-described antibiotic production by different members of Pseudomonas ${ }^{103}$ may effectively suppress bacterial competitors, and might be another explanation for the decreased stability of the biofilm matrix. Duffy and Defago ${ }^{104}$ reported that secondary algal metabolites, such as sugar alcohols, can even be used by Pseudomonas to increase antibiotic production. Although abiotic factors should not be ruled out as influencing factors, it might be hypothesized that in a complex multispecies biofilm, the Pseudomonas specimen might start chemical warfare against competing bacteria and thereby delay algal development, due to a lack of sufficient bacteria creating favorable surface features. When the biofilm system gradually changes with the development of algae, Pseudomonas might be able to increase its antibiotic production due to algal exudates, which may increasingly impact symbiotic bacteria of the algae ${ }^{105}$ or species found in dominant abundance in very stable biofilms. An alternative might be a frequent migration to better-suited sediment 
patches, which could disrupt the biofilm matrix when a great fraction of attached bacteria change into a motile state and leave the sediment surface.

\section{Conclusion}

This study demonstrated a significant impact of the investigated abiotic boundary conditions (LI and BSS) on biofilm development. Besides having a clear effect on microbial biomass, produced EPS, and microbe-community composition, environmental conditions significantly influenced biostabilization. Cultivation under very low LI resulted in a significant reduction of biofilm development, due to the impaired growth of microalgae. This emphasizes the importance of autotrophic biofilm members for microbial biostabilization. The highest level of BSS caused a general delay in biofilm formation and biostabilization, since initial microbial settlement, especially of microalgae, was apparently hampered. However, bacteria adapted more quickly to the highly dynamic habitat than microalgae.

The results allow first insights into the roles of different key microbial players and their respective modes of life during the process of biostabilization. In biofilms with maximal stability, the dominant species among bacteria and diatoms were sessile and/or had the capacity to produce high amounts of EPS adhesives. This lifestyle correlated directly with fast reproduction and colonization of freshly exposed sediment surfaces, and may have directly enhanced the stability of the biofilm, as well as the fine underlying sediment. Minimal stable biofilms were dominated by opportunistic, very flexible microbes often associated with later successional stages. These microorganisms displayed high mobility and/ or potential for elaborated forms of chemical warfare. Generally, these species may be able to profit from opportunistic strategies in many different natural niches. However, their dominance apparently had adverse effects on other microbes with a higher stabilizing effect and the overall integrity and stability of the biofilm matrix. This observation may reflect the unstable, ever-changing nature of a matured biofilm system, which is characterized by a constantly high degree of attachment and detachment, as well as biological, chemical, and structural reorganization.

\section{Acknowledgments}

The authors are grateful to the DFG (Deutsche Forschungsgemeinschaft) for financing the project "Ecosystem engineering: sediment entrainment and flocculation mediated by microbial produced extracellular polymeric substances (EPS)" (GZ: GE 1932/3-1 and GE 1932/3-2). The authors thank the excellent support at the Institute of Functional Interfaces, Karlsruhe Institute of Technology (KIT; Professor Kerstin Matthies) and the Centre for Applied Geosciences (ZAG), University of Tübingen (Dr Sebastian Behrens, Professor A Kappler). The authors appreciate the cooperation with Dr Lydia King in diatom identification and Dr M Schweikert, Institute of Zoology, University of Stuttgart for providing their facilities.

\section{Disclosure}

The authors report no conflicts of interest in this work.

\section{References}

1. Kwon KW, Shim HJ, Bae WK, Oh JH, Bae JS. Simultaneous biodegradation of carbon tetrachloride and trichloroethylene in a coupled anaerobic/aerobic biobarrier. J Hazard Mater. 2016;313:60-67.

2. Lai CY, Zhong L, Zhang Y, et al. Bioreduction of chromate in a methane-based membrane biofilm reactor. Environ Sci Technol. 2016;50(11):5832-5839.

3. Müller-Steinhagen H, Malayeri MR, Watkinson AP. Heat exchanger fouling: mitigation and cleaning strategies. Heat Transf Eng. 2011;32(3-4):189-196.

4. Trueba A, Garca S, Otero FM, Vega LM, Madariaga E. Influence of flow velocity on biofilm growth in a tubular heat exchanger-condenser cooled by seawater. Biofouling. 2015;31(6):527-534.

5. Moreira JM, Fulgencio R, Oliveira F, et al. Evaluation of SICON surfaces for biofouling mitigation in critical process areas. Food Bioprod Process. 2016;98:173-180.

6. Mueller M, Pander J, Wild R, Lueders T, Geist J. The effects of stream substratum texture on interstitial conditions and bacterial biofilms: methodological strategies. Limnologica. 2013;43(2):106-113.

7. Blenkinsopp SA, Lock MA. The impact of storm-flow on river biofilm architecture. J Phycol. 1994;30(5):807-818.

8. Romani AM, Giorgi A, Acuna V, Sabater S. The influence of substratum type and nutrient supply on biofilm organic matter utilization in streams. Limnol Oceanogr. 2004;49(5):1713-1721.

9. Marcarelli AM, Bechtold HA, Rugenski AT, Inouye RS. Nutrient limitation of biofilm biomass and metabolism in the Upper Snake River basin, southeast Idaho, USA. Hydrobiologia. 2009;620(1):63-76.

10. Kendrick MR, Huryn AD. Discharge, legacy effects and nutrient availability as determinants of temporal patterns in biofilm metabolism and accrual in an arctic river. Freshw Biol. 2015;60(11):2323-2336.

11. Lawrence JR, Chenier MR, Roy R, et al. Microscale and molecular assessment of impacts of nickel, nutrients, and oxygen level on structure and function of river biofilm communities. Appl Environ Microbiol. 2004;70(7):4326-4339.

12. Wagner K, Besemer K, Burns NR, Battin TJ, Bengtsson MM. Light availability affects stream biofilm bacterial community composition and function, but not diversity. Environ Microbiol. 2015;17(12):5036-5047.

13. Saleem M, Fetzer I, Harms H, Chatzinotas A. Diversity of protists and bacteria determines predation performance and stability. ISME J. 2013;7(10):1912-1921.

14. Saleem M, Meckes N, Pervaiz Z, Traw M. Microbial interactions in the phyllosphere increase plant performance under herbivore biotic stress. Front Microbiol. 2017;8:41.

15. Underwood GJ, Paterson DM. Seasonal changes in diatom biomass, sediment stability and biogenic stabilization in the Severn Estuary. J Mar Biol Assoc U.K. 1993;73(4):871-887.

16. Taylor IS, Paterson DM, Mehlert A. The quantitative variability and monosaccharide composition of sediment carbohydrates associated with intertidal diatom assemblages. Biogeochemistry. 1999;45(3):303-327. 
17. Tolhurst J, Gust G, Paterson D. The influence of an extracellular polymeric substance (EPS) on cohesive sediment stability. Proc Mar Sci. 2002;5:409-425.

18. Yallop ML, Paterson DM, Wellsbury P. Interrelationships between rates of microbial production, exopolymer production, microbial biomass, and sediment stability in biofilms of intertidal sediments. Microb Ecol. 2000;39(2):116-127.

19. Gerbersdorf SU, Bittner R, Lubarsky H, Manz W, Paterson DM. Microbial assemblages as ecosystem engineers of sediment stability. J Soils Sediments. 2009;9(6):640-652.

20. Wustman BA, Gretz MR, Hoagland KD. Extracellular matrix assembly in diatoms (Bacillariophyceae) - 1: a model of adhesives based on chemical characterization and localization of polysaccharides from the marine diatom Achnanthes longipes and other diatoms. Plant Physiol. 1997;113(4):1059-1069.

21. Wustman BA, Lind J, Wetherbee R, Gretz MR. Extracellular matrix assembly in diatoms (Bacillariophyceae) - III: organization of fucoglucuronogalactans within the adhesive stalks of Achnanthes longipes. Plant Physiol. 1998;116(4):1431-1441.

22. Wang Y, Chen Y, Lavin C, Gretz MR. Extracellular matrix assembly in diatoms (Bacillariophyceae) - IV: ultrastructure of Achnanthes longipes and Cymbella cistula as revealed by high-pressure freezing/ freeze substituton [sic] and cryo-field emission scanning electron microscopy. Journal of Phycology. 2000;36(2):367-378.

23. Schmidt $H$, Thom M, Matthies $K$, et al. A multi-disciplinarily designed mesocosm to address the complex flow-sediment-ecology tripartite relationship on the microscale. Environ Sci Eur. 2015;27:2.

24. Thom M, Schmidt H, Gerbersdorf SU, Wieprecht S. Seasonal biostabilization and erosion behavior of fluvial biofilms under different hydrodynamic and light conditions. Int J Sediment Res. 2015;30(4):273-284.

25. Gerbersdorf SU, Schubert H. Vertical migration of phytoplankton in coastal waters with different UVR transparency. Environ Sci Eur. 2011;23:36.

26. Schmidt H, Thom M, King L, Wieprecht S, Gerbersdorf SU. The effect of seasonality upon the development of lotic biofilms and microbial biostabilisation. Freshw Biol. 2016;61(6):963-978.

27. Battin TJ, Sloan WT, Kjelleberg S, et al. Microbial landscapes: new paths to biofilm research. Nat Rev Microbiol. 2007;5(1):76-81.

28. Gerbersdorf SU, Manz W, Paterson DM. The engineering potential of natural benthic bacterial assemblages in terms of the erosion resistance of sediments. FEMS Microbiol Ecol. 2008;66(2):282-294.

29. Dubois M, Gilles KA, Hamilton JK, Rebers PA, Smith F. Colorimetric method for determination of sugars and related substances. Anal Chem. 1956;28(3):350-356.

30. Raunkjaer K, Hvitvedjacobsen T, Nielsen PH. Measurement of pools of protein, carbohydrate and lipid in domestic wastewater. Water Res. 1994;28(2):251-262.

31. Frølund B, Palmgren R, Keiding K, Nielsen PH. Extraction of extracellular polymers from activated sludge using a cation exchange resin. Water Res. 1996;30(8):1749-1758.

32. Battarbee R. Diatom analysis. In: Ralska-Jasiewiczowa M, Berglund BE, editors. Handbook of Holocene Palaeoecology and Palaeohydrology. Hoboken (NJ) Wiley; 1986.

33. Krammer K, Lange-Bertalot H. Bacillariophyceae. In: Ettl H, Gerloff J, Heyning H, Mollenhauer D, editors. Süßwasserflora von Mitteleuropa: Band 1-4. Jena, Germany: Gustav Fischer Verlag; 1986-1991.

34. Hofmann G, Werum M, Lange-Bertalot H. Diatomeen im SüßwasserBenthos von Mitteleuropa. Ruggell, Liechtenstein: AR Gantner Verlag; 2011.

35. Shannon CE, Weaver W. The Mathematical Theory of Communication. Champaign (IL): University of Illinois Press; 1963.

36. Lane D. $16 \mathrm{~S} / 23 \mathrm{~S}$ rRNA sequencing. In: Stackebrandt E, Goodfellow M, editors. Nucleic Acid Sequencing Techniques in Bacterial Systematics. Hoboken (NJ): Wiley; 1990:115-148.

37. Emtiazi F, Schwartz T, Marten SM, Krolla-Sidenstein P, Obst U. Investigation of natural biofilms formed during the production of drinking water from surface water embankment filtration. Water Res. 2004;38(5):1197-1206.
38. Muyzer G, Dewaal EC, Uitterlinden AG. Profiling of complex microbial populations by denaturing gradient gel electrophoresis analysis of polymerase chain reaction-amplified genes coding for 16S rRNA. Appl Environ Microbiol. 1993;59(3):695-700.

39. Marzorati M, Wittebolle L, Boon N, Daffonchio D, Verstraete W. How to get more out of molecular fingerprints: practical tools for microbial ecology. Environ Microbiol. 2008;10(6):1571-1581.

40. Lorenz MO. Methods of measuring the concentration of wealth. JAm Stat Assoc. 1905;9(70):209-219.

41. Pruesse E, Quast C, Knittel K, et al. SILVA: a comprehensive online resource for quality checked and aligned ribosomal RNA sequence data compatible with ARB. Nucleic Acids Res. 2007;35(21): 7188-7196.

42. Larson F, Lubarsky H, Gerbersdorf SU, Paterson DM. Surface adhesion measurements in aquatic biofilms using magnetic particle induction: MagPI. Limnol Oceanogr Methods. 2009;7(7):490-497.

43. Kalmbach S, Manz W, Wecke J, Szewzyk U. Aquabacterium gen. nov., with description of Aquabacterium citratiphilum sp. nov., Aquabacterium parvum sp. nov. and Aquabacterium commune sp. nov., three in situ dominant bacterial species from the Berlin drinking water system. Int J Syst Bacteriol. 1999;49:769-777.

44. Vancanneyt M, Segers P, Abraham W, De Vos P. Brevundimonas. In: Garrity G, editor. Bergey's Manual of Systematic Bacteriology. Vol 2. New York: Springer; 2009:308-316.

45. Zeng Y, Selyanin V, Lukeš M, et al. Characterization of the microaerophilic, bacteriochlorophyll a-containing bacterium Gemmatimonas phototrophica sp nov., and emended descriptions of the genus Gemmatimonas and Gemmatimonas aurantiaca. Int J Syst Bacteriol. 2015;65:2410-2419.

46. Zeng Y, Baumbach J, Barbosa EG, Azevedo V, Zhang C, Kobližek M. Metagenomic evidence for the presence of phototrophic Gemmatimonadetes bacteria in diverse environments. Environ Microbiol Reports. 2016;8(1):139-149.

47. Wawrousek K, Noble S, Korlach J, et al. Genome annotation provides insight into carbon monoxide and hydrogen metabolism in Rubrivivax gelatinosus. PloS One. 2014;9(12):e114551.

48. Kaden R, Sproeer C, Beyer D, Krolla-Sidenstein P. Rhodoferax saidenbachensis sp nov., a psychrotolerant, very slowly growing bacterium within the family Comamonadaceae, proposal of appropriate taxonomic position of Albidiferax ferrireducens strain $\mathrm{T}_{11} 8^{\mathrm{T}}$ in the genus Rhodoferax and emended description of the genus Rhodoferax. Int J Syst Evol Microbiol. 2014;64:1186-1193.

49. Dvořák P, Hindák F, Hašler P, Hindáková A, Poulíčková A. Morphological and molecular studies of Neosynechococcus sphagnicola, gen. et sp nov (Cyanobacteria, Synechococcales). Phytotaxa. 2014;170(1):24-34.

50. Kanellopoulos C, Lamprinou V, Mitropoulos P, Voudouris P. Thermogenic travertine deposits in Thermopylae hot springs (Greece) in association with cyanobacterial microflora. Carbonates Evaporites. 2015;31(3):239-248.

51. DeNicola DM, McIntire CD. Effects of substrate relief on the distribution of periphyton in laboratory streams -1 : hydrology. J Phycol. 1990;26(4):624-633.

52. Horn H, Hempel DC. Modeling mass transfer and substrate utilization in the boundary layer of biofilm systems. Water Sci Technol. 1998;37(4-5):139-147.

53. Holtappels M, Lorke A. Estimating turbulent diffusion in a benthic boundary layer. Limnol Oceanogr Methods. 2011;9(1):29-41.

54. Rasmussen K, Lewandowski Z. Microelectrode measurements of local mass transport rates in heterogeneous biofilms. Biotechnol Bioeng. 1998;59(3):302-309.

55. Stewart PS. Mini-review: convection around biofilms. Biofouling. 2012;28(2):187-198.

56. Gashti MP, Bellavance J, Kroukamp O, Wolfaardt G, Taghavi SM, Greener J. Live-streaming: time-lapse video evidence of novel streamer formation mechanism and varying viscosity. Biomicrofluidics. 2015;9(4):041101. 
57. Fink R, Oder M, Rangus D, Raspor P, Bohinc K. Microbial adhesion capacity: influence of shear and temperature stress. Int J Environ Health Res. 2015;25(6):656-669.

58. Moreira JM, Simoes M, Melo LF, Mergulhao FJ. The combined effects of shear stress and mass transfer on the balance between biofilm and suspended cell dynamics. Desalination Water Treat. 2015;53(12):3348-3354.

59. Willkomm M, Schlüssell A, Reiz E, Arndt H. Effects of microcurrents in the boundary layer on the attachment of benthic heterotrophic nanoflagellates. Aquat Microb Ecol. 2007;48(2):169-174.

60. Pohlon E, Marxsen J, Küsel K. Pioneering bacterial and algal communities and potential extracellular enzyme activities of stream biofilms. FEMS Microbiol Ecol. 2010;71(3):364-373.

61. Coundoul F, Bonometti T, Graba M, Sauvage S, Perez JM, Moulin FY. Role of local flow conditions in river biofilm colonization and early growth. River Res Appl. 2015;31(3):350-367.

62. Lemos M, Mergulhao F, Melo L, Simoes M. The effect of shear stress on the formation and removal of Bacillus cereus biofilms. Food Bioprod Process. 2015;93:242-248.

63. Peyton BM, Characklis WG. A statistical-analysis of the effect of substrate utilization and shear-stress on the kinetics of biofilm detachment. Biotechnol Bioeng. 1993;41(7):728-735.

64. Choi YC, Morgenroth E. Monitoring biofilm detachment under dynamic changes in shear stress using laser-based particle size analysis and mass fractionation. Water Sci Technol. 2003;47(5):69-76.

65. Roeselers G, Van Loosdrecht MC, Muyzer G. Heterotrophic pioneers facilitate phototrophic biofilm development. Microb Ecol. 2007;54(3):578-585.

66. D'Costa PM, Anil AC. Penicillin-mediated changes in viable benthic diatom assemblages: insights about the relevance of bacteria across spatial and seasonal scales. Mar Freshw Res. 2014;65(5):437-452.

67. Hermansson M. The DLVO theory in microbial adhesion. Colloids Surf B Biointerfaces. 1999;14(1-4):105-119.

68. Li GL, Tam LK, Tang JX. Amplified effect of Brownian motion in bacterial near-surface swimming. Proc Natl Acad Sci U S A. 2008; 105(47):18355-18359.

69. Hoffman MD, Zucker LI, Brown PJ, Kysela DT, Brun YV, Jacobson SC. Timescales and frequencies of reversible and irreversible adhesion events of single bacterial cells. Anal Chem. 2015;87(24):12032-12039.

70. Deweger LA, van der Vlugt CI, Wijfjes AH, Bakker P, Schippers B, Lugtenberg B. Flagella of a plant-growth-simulating Pseudomonas fluorescens strain are required for colonization of potato roots. $\mathrm{J} \mathrm{Bac}$ teriol. 1987;169(6):2769-2773.

71. Bruzaud J, Tarrade J, Coudreuse A, et al. Flagella but not type IV pili are involved in the initial adhesion of Pseudomonas aeruginosa PAO1 to hydrophobic or superhydrophobic surfaces. Colloids Surf B Biointerfaces. 2015;131:59-66.

72. Yoshihara A, Nobuhira N, Narahara H, et al. Estimation of the adhesive force distribution for the flagellar adhesion of Escherichia coli on a glass surface. Colloids Surf B Biointerfaces. 2015;131:67-72.

73. Gu H, Chen A, Song XR, Brasch ME, Henderson JH, Ren DC. How Escherichia coli lands and forms cell clusters on a surface: a new role of surface topography. Scientific Reports. 2016;6:29516.

74. Fang HH, Chan KY, Xu LC. Quantification of bacterial adhesion forces using atomic force microscopy (AFM). J Microbiol Methods. 2000;40(1):89-97.

75. Geider RJ, MacIntyre HL, Kana TM. A dynamic regulatory model of phytoplanktonic acclimation to light, nutrients, and temperature. Limnol Oceanogr. 1998;43(4):679-694.

76. Li X, Hu HY, Gan K, Sun YX. Effects of different nitrogen and phosphorus concentrations on the growth, nutrient uptake, and lipid accumulation of a freshwater microalga Scenedesmus sp. Bioresour Technol. 2010;101(14):5494-5500.

77. Prieto DM, Devesa-Rey R, Rubinos DA, Diaz-Fierros F, Barral MT. Biofilm formation on river sediments under different light intensities and nutrient inputs: a flume mesocosm study. Environ Eng Sci. 2016;33(4):250-260.
78. Lange K, Liess A, Piggott JJ, Townsend CR, Matthaei CD. Light, nutrients and grazing interact to determine stream diatom community composition and functional group structure. Freshw Biol. 2011;56(2):264-278.

79. Bowes MJ, Ings NL, McCall SJ, et al. Nutrient and light limitation of periphyton in the River Thames: Implications for catchment management. Sci Total Environ. 2012;434:201-212.

80. Zippel B, Neu TR. Growth and structure of phototrophic biofilms under controlled light conditions. Water Sci Technol. 2005;52(7):203-209.

81. Havskum H, Thingstad TF, Scharek R, et al. Silicate and labile DOC interfere in structuring the microbial food web via algal-bacterial competition for mineral nutrients: results of a mesocosm experiment. Limnol Oceanogr. 2003;48(1):129-140.

82. Sack EL, van der Wielen P, van der Kooij D. Polysaccharides and proteins added to flowing drinking water at microgram-per-liter levels promote the formation of biofilms predominated by Bacteroidetes and Proteobacteria. Appl Environ Microbiol. 2014;80(8):2360-2371.

83. Agogué H, Mallet C, Orvain F, De Crignis M, Mornet F, Dupuy C. Bacterial dynamics in a microphytobenthic biofilm: a tidal mesocosm approach. J Sea Re. 2014;92:36-45.

84. Riber HH, Wetzel RG. Boundary-layer and internal diffusion effects on phosphorus fluxes in lake periphyton. Limnol Oceanogr. 1987;32(6):1181-1194.

85. Paul BJ, Duthie H. Nutrient cycling in the epilithon of running waters Can J Bot. 1989;67(8):2302-2309.

86. Burkholder JM, Wetzel RG, Klomparens KL. Direct comparison of phosphate-uptake by adnate and loosely attached microalgae within an intact biofilm matrix. Appl Environ Microbiol. 1990;56(9): 2882-2890.

87. Mulholland PJ, Steinman AD, Marzolf ER, Hart DR, DeAngelis DL. Effect of periphyton biomass on hydraulic characteristics and nutrient cycling in streams. Oecologia. 1994;98(1):40-47.

88. Peterson CG. Response of benthic algal communities to natural physical disturbance. In: Stevenson RJ, Bothwell ML, Lowe RL, editors Algal Ecology: Freshwater Benthic Ecosystems. San Diego: Academic Press; 1996:375-402.

89. Hay SI, Maitland TC, Paterson DM. The speed of diatom migration through natural and artificial substrata. Diatom Res. 1993;8(2):371-384.

90. Poff NL, Ward JV. Herbivory under different flow regimes: a field experiment and test of a model with a benthic stream insect. Oikos. 1995;72(2):179-188.

91. Law RJ, Elliott JA, Jones ID, Page T. The influence of different environmental conditions upon the initial development and ecological dynamics of phytobenthic communities. Fundam Appl Limnol. 2014;185(2):139-153.

92. Havens KE, East TL, Meeker RH, Davis WP, Steinman AD. Phytoplankton and periphyton responses to in situ experimental nutrient enrichment in a shallow subtropical lake. J Plankton Res. 1996;18(4):551-566.

93. Tichi MA, Tabita FR. Interactive control of Rhodobacter capsulatus redox-balancing systems during phototrophic metabolism. J Bacteriol. 2001;183(21):6344-6354.

94. Urakami T, Araki H, Oyanagi H, Suzuki KI, Komagata K. Paracoccus aminophilus sp-nov and Paracoccus aminovorans sp-nov, which utilize N,N-dimethylformamide. Int J Syst Bacteriol. 1990;40(3):287-291.

95. Onder O, Aygun-Sunar S, Selamoglu N, Daldal F. A glimpse into the proteome of phototrophic bacterium Rhodobacter capsulatus. Adv Exp Med Biol. 2010;675:179-209.

96. Brimacombe CA, Stevens A, Jun D, Mercer R, Lang AS, Beatty JT. Quorum-sensing regulation of a capsular polysaccharide receptor for the Rhodobacter capsulatus gene transfer agent (RcGTA). Mol Microbiol. 2013;87(4):802-817.

97. Dziewit L, Czarnecki J, Wibberg D, et al. Architecture and functions of a multipartite genome of the methylotrophic bacterium Paracoccus aminophilus JCM 7686, containing primary and secondary chromids. BMC Genomics. 2014;15:124. 
98. de Weert S, Vermeiren H, Mulders IH, et al. Flagella-driven chemotaxis towards exudate components is an important trait for tomato root colonization by Pseudomonas fluorescens. Mol Plant Microbe Interact. 2002;15(11):1173-1180.

99. Henrici AT, Johnson DE. Studies of freshwater bacteria - II: stalked bacteria, a new order of schizomycetes. J Bacteriol. 1935;30(1):61-93.

100. Ping LY, Birkenbeil J, Monajembashi S. Swimming behavior of the monotrichous bacterium Pseudomonas fluorescens SBW25. FEMS Microbiol Ecol. 2013;86(1):36-44.

101. Mastropaolo MD, Silby MW, Nicoll JS, Levy SB. Novel genes involved in Pseudomonas fluorescens Pf0-1 motility and biofilm formation. Appl Environ Microbiol. 2012;78(12):4318-4329.
102. Decoin V, Gallique M, Barbey C, et al. A Pseudomonas fluorescens type 6 secretion system is related to mucoidy, motility and bacterial competition. BMC Microbiol. 2015;15:72.

103. Raaijmakers JM, Weller DM, Thomashow LS. Frequency of antibioticproducing Pseudomonas spp. in natural environments. Appl Environ Microbiol. 1997;63(3):881-887.

104. Duffy BK, Defago G. Environmental factors modulating antibiotic and siderophore biosynthesis by Pseudomonas fluorescens biocontrol strains. Appl Environ Microbiol. 1999;65(6):2429-2438.

105. Amin SA, Parker MS, Armbrust EV. Interactions between diatoms and bacteria. Microbiol Mol Biol Rev. 2012;76(3):667-679.

\section{Publish your work in this journal}

Research and Reports in Biology is an international, peer-reviewed, open access journal publishing original research, reports, editorials, reviews and commentaries on all areas of biology including animal biology, biochemical biology, cell biology, ecological studies, evolutionary biology, molecular biology, plant science and botany. The manuscript management system is completely online and includes a very quick and fair peer-review system. Visit http://www.dovepress. com/testimonials.php to read real quotes from published authors. 